\title{
He mihi whakatau (Editorial)
}

\section{Riki Paniora}

Toitu whenua, Toit tangata, Toitu Mana Tane. Whakarongo, Whakarongo,Whakarongo, Tamatane ma o te whare o Iharaira. Kua karanga Te Atua puta atu i te pouri ki te tino ao marama. Haeremai, kia mataara, kia inoi, kia he ai ko Hatana. Haeremai, ruia nga kakano o te matauranga, te whakapono, tumanako me te aroha ki nga iwi whanau hapu i nga iwi katoa o te ao. Hauime, hui e, taiki e!

Respectful acknowledgement binds people, land and tane Maori. Listen, hear and draw near to your values and beliefs as you find your way through manhood into the world of enlightenment. Come, be alert, use your spiritual tools, to combat all types of adversity. Openly sow those treasures of wisdom, faith, hope and charity to not only yours but all. Woven as a beacon for all!

The difference between men and women:

A man was driving up a steep, narrow mountain road. A woman is driving down the same road. As they pass each other the woman leans out the window and yells: 'PIG!!'

The man immediately leans out his window and replies with 'B------!!'

They each continue on their way and as the man rounds the next corner he slams into a pig in the middle of the road. (Jokes.Net)

\section{Welcome to Tane-ville}

Welcome to the first issue of Te Komako devoted to tane Maori who work within the terrain of social and community work. The photo in the contents page is a reflection of a journey in creating taonga from pounamu during a three-day wananga for a whanau including four brothers, a son and two extended whanau members, and facilitated by a first cousin.

Tane-ville is a place where tane interact with tane. It is a place where we can express who we are as men that have common experiences. It is a place of safety where we can talk about those things that are important to us, such as how can we be more effective in bringing about change within our fields of practice thrown in with how the Warriors are going and what can be done to improve the All Blacks. It is a place where we laugh together and at each other and ultimately it is a place where we can refurbish and refresh our ahua, our ngakau and our wairua.

To this end this edition is a celebration of a compilation of various topics with one common denominator, all contributors are tane Maori.

We begin with an article published in 1967 in NZSW News and Opinions (Vol. 3, No. 4 November 1967) written by the late rangatira John Rangihau titled 'Maori Culture Today'.

This pu korero of yesteryear is contrasted with a contemporary article from a grandfather, son and mokopuna; a three-generational korero that delves into the realms of mana tangata supervision.

E mihi atu kia Koutou e te rangatira Pirihi Te Ohaki Ruwhiu, te tama Dr Leland Ariel Ruwhiu, te tama/mokopuna Leland Lowe Hyde Ruwhiu. 
The two articles were written in different time periods, but they both address a similar issue of tangata whenua wellbeing.

We then move onto four articles that reflect on what it is like to be a bloke and the impact that this identity has on the mahi engagement. Acknowledgement to Dr Peter Mataira, Anaru Eketone, Karl Pearce and myself.

The last three articles provide an interesting, diverse array of practice issues concluding with an ode. Acknowledgement therefore goes out to Newton Thompson, Shayne Walker and Henry Kemp.

Alan Duff's analogy of Once were Warriors painted somewhat of a stereotype for tane, in which social and community work was perceived as a disaster area for men, as they were often seen as the cause of many of the social ills that have affected our communities.

The impact of this perception had caused tane to traverse this terrain with much caution. It is not surprising that men are a minority in social and community work. What is it then about that minority group that firstly makes them want to be in that terrain and secondly keeps them there?

To this end, not only were Maori men once warriors but they were once philosophers, poets and lovers.

The wero for you the reader is to carry on the korero. We might suggest that these articles are well worth further discussion in groups or with colleagues and friends. The depth of korero needs to be understood to gain the most from this issue. So, welcome to Tane-ville. 